Provided for non-commercial research and education use. Not for reproduction, distribution or commercial use.

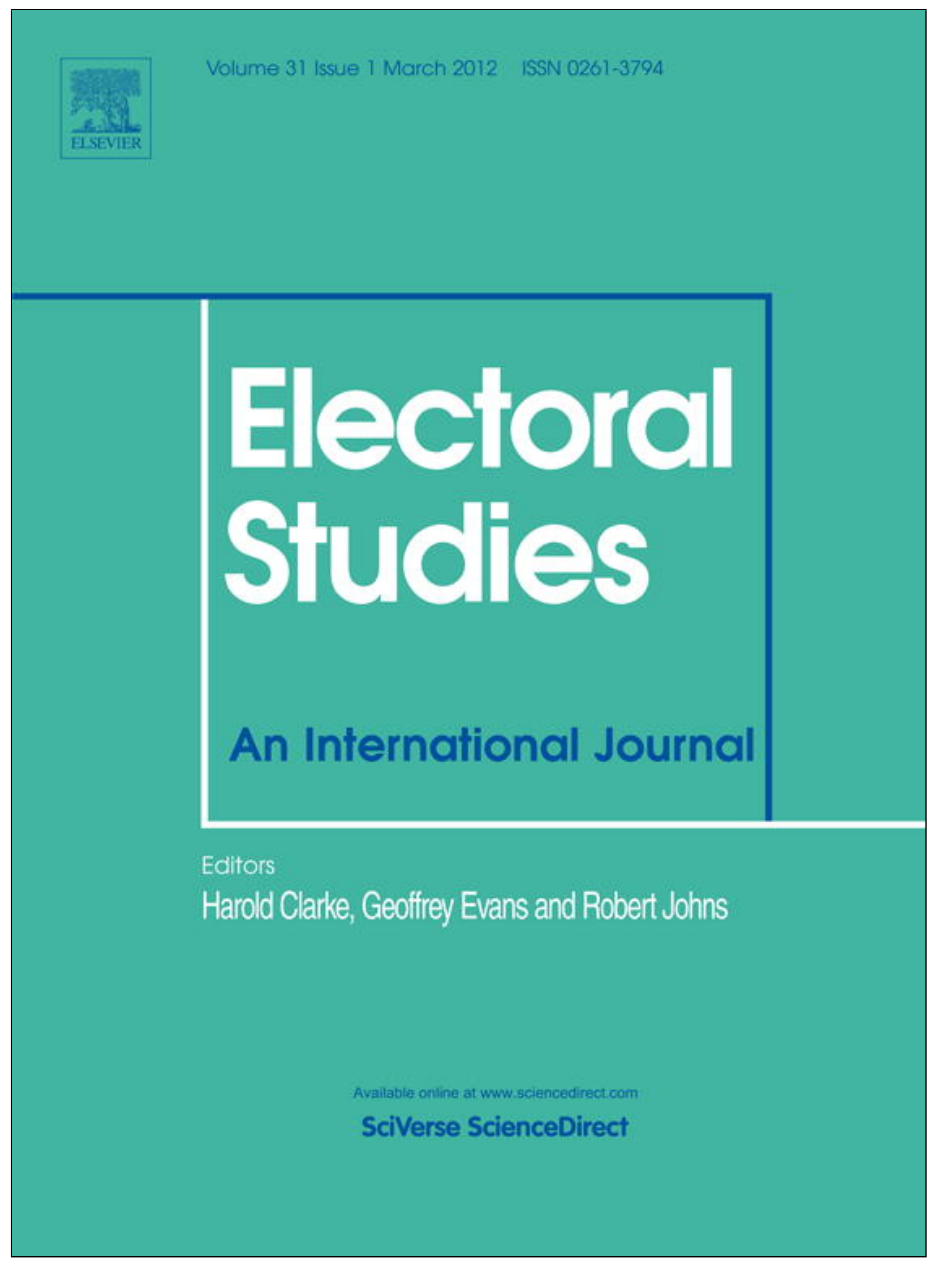

This article appeared in a journal published by Elsevier. The attached copy is furnished to the author for internal non-commercial research and education use, including for instruction at the authors institution and sharing with colleagues.

Other uses, including reproduction and distribution, or selling or licensing copies, or posting to personal, institutional or third party websites are prohibited.

In most cases authors are permitted to post their version of the article (e.g. in Word or Tex form) to their personal website or institutional repository. Authors requiring further information regarding Elsevier's archiving and manuscript policies are encouraged to visit:

http://www.elsevier.com/copyright 


\title{
Not always second order: Subnational elections, national-level vote intentions, and volatility spillovers in a multi-level electoral system ${ }^{\text {ts }}$
}

\author{
Michael M. Bechtel* \\ ETH Zurich, Center for Comparative and International Studies, IFW C45.2, Haldeneggsteig 4, CH-8092 Zurich, Switzerland
}

\section{A R T I C L E I N F O}

\section{Article history:}

Received 20 February 2011

Received in revised form 7 October 2011

Accepted 10 October 2011

\section{Keywords:}

Vote intentions

Electoral campaigns

Subnational elections

Multi-level systems

Electoral institutions

\begin{abstract}
A B S T R A C T
The widespread second-order view on subnational elections leaves little room for the idea that subnational election campaigns matter for national-level electoral preferences. I challenge this perspective and explore the context-conditional role of subnational election campaigns for national-level vote intentions in multi-level systems. Campaigns direct citizens' attention to the political and economic "fundamentals" that determine their electoral preferences. Subnational election campaigns and the major campaign issues receive nation-wide media coverage. This induces all citizens in a country to evaluate parties at the national level even if they themselves are not eligible to vote in the upcoming subnational election. Thereby, subnational election campaigns may lead to a reduction in the uncertainty of voters' national-level electoral preferences throughout the country, which is reflected by a decrease in the volatility of national-level vote intentions. I explore weekly vote intention data from Germany (1992-2007) within a conditional volatility model. Subnational elections reduce uncertainty in nation-wide federal-level vote intentions for major parties. However, patterns of incumbency and coalitional shifts moderate this volatility-reducing effect.
\end{abstract}

(c) 2011 Elsevier Ltd. All rights reserved.
Scholarly interest in the political and economic determinants of vote intentions enjoys a long tradition in political science (Matthews and Johnston, 2010; Clarke et al., 1998; Fiorina, 1978). Several developments have fueled these research efforts in the last decade. First, voter alignments in industrial democracies have experienced a persistent, long-term decline (Wattenberg, 2000). Since citizens' long-term partisan attachments explain ever less of the observed variance in vote intentions and electoral behavior, researchers theorize about which other factors play a role for electoral preferences. Second, parties and candidates devote ever more financial resources to

\footnotetext{
is I thank Gary W. Cox, Marc Debus, Jens Hainmueller, Dominik Hangartner, and Peter Selb for sharing their insightful thoughts and comments on earlier versions of this paper. The usual disclaimer applies. Supplementary information and replication data for this article are available at www.ib.ethz.ch/people/mbechtel.

* Tel.: +41 446326268.

E-mail address: mbechtel@ethz.ch.
}

electoral campaigns. The increase appears particularly strong for subnational elections. For example, campaign spending in gubernatorial elections in the United States has multiplied by a factor of 10 in the last two decades, from about \$11 million in 1988 to \$118 million in 2008 (Jensen and Beyle, 2003) and this growth clearly exceeds spending increases in presidential elections, which have merely grown by a factor of $6 .^{1}$ This provokes the question whether these ever more expensive campaigns that receive considerable nation-wide media coverage affect electoral preferences beyond their local context. Third, there has been a strong increase in the variability of vote intentions prior to elections (Gelman and King, 1993). Therefore, especially in periods when demand for accurate election forecasts among candidates and the interested public

\footnotetext{
Spending in presidential campaigns has increased from $\$ 210$ million in 1988 to $\$ 1325$ million in 2008 (www.opensecrets.org/pres08/totals. php\%3fcycle $=2008$ ).
} 
peaks, the strong variability of vote intentions severely limits the precision with which these predictions can be made.

Of course, studying volatility in vote intentions promises insights for reasons that go beyond the wish to predict electoral outcomes, evaluate established theories of electoral behavior, or assess the effects of election campaigns. On normative grounds, electoral support constitutes a crucial and maybe the only valid source of political legitimacy in democratic systems. Gronke and Brehm (2002) point out that if high-levels of stable electoral support backs governments and parties, their actions appear more justified than in periods of strong fluctuations in political popularity. Political popularity may also represent a resource in international politics. A government that can credibly claim to be backed by stable electoral support domestically can use this fact as a power resource in international bargaining (Schultz, 1998; Putnam, 1988; Schelling, 1960).

Orthodox scholarship views national-level vote intentions as a function of national-level factors, for example, the state of the economy, incumbency, single political events, or national-level election campaigns and the related campaign issues (Bechtel and Hainmueller, 2011; Shaw and Roberts, 2000; Lewis-Beck and Paldam, 2000; Gerber and Lupia, 1995). Inspired by the second-order election theory, researchers have also devoted great effort to explore the effects of national-level economic and political factors on subnational elections (Kedar, 2006; Kern and Hainmüller, 2006; Lohmann et al., 1997). Thereby, research has concentrated on top-down spillovers, i.e., effects of national politics on electoral preferences at the subnational level. This second-order view on subnational elections, however, leaves little room for the idea that subnational factors may systematically affect volatility in voters' preferences at the national level (bottom-up volatility spillover). Although the literature on subnational and multilevel electoral politics has grown substantially in the last decade, we know virtually nothing about whether and how subnational elections influence vote intentions at the national-level.

This paper develops and empirically evaluates predictions about bottom-up volatility spillovers in multi-level systems and thereby adds to scholarship on interaction effects among electoral institutions. I advance a perspective on subnational elections that takes as its point of departure the informational role of subnational electoral campaigns and their effects on voter uncertainty. Such bottom-up volatility spillovers have not yet been studied. Subnational election campaigns provide voters with an opportunity to learn about the economic and political fundamentals that determine their electoral preferences. Information revealed during subnational electoral campaigns also reaches citizens who are not eligible to cast a ballot in the upcoming subnational election because nation-wide television channels, radio stations, and newspapers cover political issues in the run-up to election day. This increases general interest in political and economic issues and provides valuable information about the variables that affect voters' electoral preferences. Moreover, in nationalized party systems where the same parties operate at both the national and the subnational level, all citizens (not just those in the subnational jurisdiction facing an election) can learn about their performance, general policy stance, and success in choosing competent candidates.

This reasoning leads to several empirically observable implications, some of which are conditional on the institutional and partisan context in which subnational elections take place. Subnational election campaigns should reduce the volatility in national-level vote intentions, because they induce voters to pay attention to and learn about the economic and political variables that determine their electoral preferences. Such bottom-up volatility spillover effects rest on the widely accepted argument that campaigns reduce the uncertainty associated with the variables that voters use to make up their minds (Wlezien and Erickson, 2002; Gronke and Brehm, 2002; Gelman and King, 1993). If voters perceive these variables as very uncertain, i.e., associated with large confidence intervals, their vote intentions will be very volatile as well. However, if the estimates of variables in the individuals' vote choice function are more certain - due to increased interest in political issues and information provided during the subnational electoral campaign - electoral preferences will be associated with smaller confidence intervals. Consequently, the campaign period preceding subnational elections should be associated with a significant reduction in the volatility of national-level vote intentions. The informational role of subnational elections, however, may also vary as a function of subnational party incumbency, incumbency congruence (whether the same party is the incumbent at both, the national and the subnational level), and coalitional shifts. For example, if subnational elections are associated with a change in the governing coalition, they may actually increase voter uncertainty about their national-level electoral preferences.

Empirically, this paper explores bottom-up volatility spillovers of state election campaigns using weekly, federal-level vote intention series from Germany, 1992 to 2007. The results suggest that state election campaigns indeed matter for vote intentions at the federal level. I find that state elections significantly reduce volatility in federal-level popularity of the two major German parties, the Christian Democrats (CDU) and the Social Democratic Party (SPD). The results also suggest that subnationalnational incumbency patterns and coalitional shifts moderate the volatility-reducing effect of subnational elections. $^{2}$ I conclude that scholarship should take into account bottom-up spillovers when studying higher-level electoral preferences and identify questions for further research on interactions among electoral institutions, party support, and voter information in multi-level settings.

\section{Top-down and bottom-up electoral spillovers}

I distinguish two types of electoral spillover effects: vertical and horizontal spillovers. Vertical spillovers occur

\footnotetext{
2 This paper defines the term "incumbency" as a situation in which a party is part of the governing coalition either at the national or at the subnational level or both.
} 
in multi-level systems, horizontal spillovers in mixed electoral systems. Horizontal spillovers denote changes in the electoral preferences in one electoral tier due to changes in another electoral tier. Contamination effects, i.e., if the presence of single-member districts affect electoral preferences in the PR tier, constitute a prime example for a horizontal spillover. Already Duverger $(1986,72)$ argued that in mixed electoral systems single-member districts and their majoritarian logic increase pressure toward a two-party system even though the presence of a proportional tier fosters a multi-party system (Cox and Schoppa, 2002; Herron and Nishikawa, 2001). Such spillover effects can operate in two directions. Contamination can occur from the proportional representation tier to the majoritarian tier and vice versa (Hainmüller and Kern, 2008; Karp, 2009).

Vertical spillovers occur in multi-level systems and again can operate in two directions. If national politics affect voter preferences in elections to subnational bodies, I term this a top-down spillover. A top-down spillover effect is, for example, a decline in the popularity of the incumbent party at the state level as a consequence of scandals in federal-level politics in which this party is involved. A bottom-up spillover effect occurs if political events at the subnational level affect electoral preferences at a higher level of the political system, for example, if a change in federal-level vote intentions occurs due to events at the state level. Note that this phenomenon constitutes a spillover across political institutions, since it involves interactions between elections to legislative institutions at different jurisdictional levels.

Past research has examined top-down spillovers extensively by applying policy moderation arguments (Fiorina, 1991; Alesina and Rosenthal, 1995) to explain voter behavior in multi-level systems, where subnational jurisdictions are represented at the national level, e.g., state governments in a second chamber at the federal level. The policy moderation argument implies a top-down spillover effect, because moderate voters should use state elections as an instrument to strengthen parties that are part of the opposition at the federal level, which leads to partisan conflict between the first and the second chamber, a situation which resembles that of divided government. Since divided government forces political actors to compromise on moderate policies, voters located at the middle of the political spectrum will be better off.

Gaines and Crombez (2004) find evidence for a "moderating elections" phenomenon in Germany and several studies demonstrate that such top-down spillover effects also exist in subnational elections (Dinkel, 1977). Kern and Hainmüller (2006) and Kedar (2006) more closely evaluate the balancing argument. They find that parties which enjoy unified government at the federal-level experience a statistically significant loss in state elections. Also in France, voters seem to take the functioning of the political system into account when casting their ballots (Geschwend and Leuffen, 2005).

Past research has almost exclusively focused on explaining subnational election outcomes as a function of national politics, and thus on top-down spillovers. This focus likely is a consequence of Reif and Schmitt's (1980) influential study, in which they term elections to the European Parliament "second-order national elections". They argue that since national parliaments constitute the most important legislative arena, citizens will either abstain in European elections, because so little is at stake, or use them as an opportunity to express their naive feelings about their national government's performance. Applied to the intra-national level, state or local elections merely function as "barometer elections" (Anderson and Ward, 1996) whose outcomes depend on national-level politics and economic conditions (Decker and von Blumenthal, 2002; Jacobson and Kernell, 1983). Most findings appear to support the second-order elections view, and consequently, this perspective has become dominant in the literature.

The second-order view, however, leaves little room for the existence of bottom-up spillovers, i.e., the idea that subnational elections and the campaigns associated with them matter for higher-level electoral preferences. ${ }^{3}$ I challenge this perspective by drawing on our knowledge about the informational effects of electoral campaigns on voter preferences to explore the impact of subnational election campaigns on volatility in national-level vote intentions.

\section{Subnational election campaigns and voter uncertainty}

Electoral campaigns play a key role for the level of information available to voters Elections incentivize political actors to inform voters about their salience and valence issues, thereby reducing voter uncertainty about parties' and candidates' policies. Election campaigns induce the media to report on political and economic issues that determine electoral preferences. Thereby, campaigns raise both the flow of information about the political and economic fundamentals and citizens' political excitement (Jackson, 1997). In contrast to Finkel (1993) "minimal effects" findings, recent research suggests that citizens indeed learn about political issues from campaign information (Norris and Sanders, 2003). The electoral behavior and political psychology literature argues that campaigns primarily work by inducing voters to pay attention to the factors on which they base their electoral preferences, for example, the state of the economy, the policy position of parties and candidates, the weight these policies are given in their multidimensional policy portfolio, and their competence. As Stevenson and Vavreck (2000) put it in their analysis of the impact of campaign length on electoral performance: "In this way, campaigns do two things - they help voters make sense of the agenda and they reduce voter uncertainty about candidate positions or real conditions of important variables" (220). This "enlightenment" argument about campaigns and their effect on voter uncertainty lies at the heart of the following analysis of the spillover effects of subnational election campaigns on volatility in nationallevel vote intentions.

\footnotetext{
3 The sole exceptions are a study by Samuels (2000) on the impact of gubernatorial elections on congressional elections in Brazil and Schain's (2006) work on the evolution of the political right in France.
} 
The argument that campaigns matter for volatility in electoral preferences can be traced back to the work by Gelman and King (1993), Wlezien and Erickson (2002), and Gronke and Brehm (2002). ${ }^{4}$ According to Gelman and King (1993) influential "learning-from-campaigns" model, electoral preferences depend on several fundamental variables about which campaigns provide information. However, these variables (parties' policies, policy salience and valence issues) are associated with uncertainty. Individuals use information provided during the campaign to obtain more accurate estimates of the variables that affect their electoral preferences. Thus, campaign information helps voters to reduce uncertainty about assessments of the variables that enter their vote choice function. Over the course of the campaign, imprecise estimates of relevant political and economic fundamentals are transformed into ones that are associated with less variability. Thereby, the deliberations taking place during election campaigns lead voters to form more stable opinions on parties' likely performance in office, which at the aggregate level induces more stable vote intentions. ${ }^{5}$

How do subnational election campaigns affect volatility in nation-wide party support? The media intensively report on subnational campaigns and campaign issues are covered in nation-wide television channels, radio stations, and newspapers in the run-up to election day. As Miller and Mackie (1973) point out in their analysis of British vote intention series, "the influences which should be considered are those which either affect many electors directly or those which are so well publicized by the media that many electors are invited to use them as criteria for judgment" (265). If a party operates at both, the national and the subnational level, all citizens (not just those in the subnational unit facing an election) can learn about its economic performance, general policy stance, and success in choosing competent candidates. As this reduces the variance in perceived political and economic fundamentals, it also affects variance in voters' electoral preferences. If the estimates of the fundamentals are very uncertain, i.e., associated with large confidence intervals, an individual's vote intention will be very volatile as well. However, if due to increased interest in political issues during subnational electoral campaigns and more relevant information the estimates of the variables that factor in the vote choice function are more certain, electoral preferences will also be associated with less uncertainty. ${ }^{6}$ At the macro level, this micro foundation leads to the expectation that the campaign period preceding subnational elections should reduce volatility in vote intentions.

\footnotetext{
${ }^{4}$ More recently, Kriner and Schwartz (2009) analyze volatility in presidential approval rates.

${ }^{5}$ In a recent contribution, Selb (2008) explicitly theorizes about how ballot length affects voter uncertainty, i.e., the volatility of citizens' electoral choices. He argues that ballot length increases voters' uncertainty about policy alternatives and thereby decreases their ability to translate their political preferences into consistent policy choices. Empirically, he finds that lengthy ballots are associated with a significant increase in the variability of voters' preferences.

6 This assumption has recently been evaluated empirically by Peterson (2009) who presents individual-level evidence indicating that voters' choices vary as a function of uncertainty about candidates.
}

Hypothesis 1. (Subnational election campaign) Volatility in national-level vote intentions is lower during subnational election campaigns.

\section{Incumbency and clarity of responsibility in multi-level systems}

The precision with which voters form their electoral preferences depends on the clarity of political responsibility (Powell and Whitten, 1993; Stevenson and Vavreck, 2000). Voters can more easily hold an incumbent party responsible for policy than an opposition party, because they cannot observe the counterfactual, i.e., what the world would look like if the opposition had won the last election. This means that an assessment of incumbency performance constitutes the primary basis for retrospective voting.

However, multi-level political systems can complicate retrospective voting, because partisanship of subnational governments and partisanship of the national government may differ. In federal systems, for example, policy change typically requires the consent of a large number of actors from different levels and provides excellent opportunities to engage in blame shifting tactics. Blame shifting tactics decrease voters' ability to assess who is responsible for policy. Especially if different parties are incumbents at the national and the subnational level, clarity of responsibility is lower than in periods of incumbency congruence, i.e., in periods where the same party or party coalition enjoys incumbency at both levels (Gschwend, 2007). While incumbency congruence has motivated a number of studies on the effects of multi-level decisionmaking on election outcomes and split-ticket voting (Hennl and Kaiser, 2008; Kedar, 2006; Kern and Hainmüller, 2006; Geschwend and Leuffen, 2005; Scheve and Tomz, 1999; Lohmann et al., 1997), its general informational role in multi-level systems and therefore its impact on the stability of electoral support has not yet been appreciated.

The clarity of responsibility argument suggests that in multi-level systems the informational value of subnational election campaigns also depends on congruence between subnational and national government partisanship. If the electorate faces a party that enjoys incumbency at both the subnational and the national level, there is almost no ambiguity in who is responsible for policy. Thus, citizens can easily hold this party accountable. Subnational election campaigns and the information disseminated throughout the preelection period will then aid voters in sharpening their electoral preferences with respect to both parties at the subnational as well as the national level. Consequently, in the time preceding subnational elections, voters' electoral preferences will vary less under conditions of incumbency congruence.

Hypothesis 2. (Incumbency congruence) Subnational election campaigns in periods of incumbency congruence are associated with a reduction in the volatility of nationallevel vote intentions.

This bottom-up volatility spillover argument obviously draws on previous research that has documented a robust and considerable incumbency advantage in elections (Hainmüller and Kern, 2008; Weisberg, 2002). This 
advantage may arise due to incumbents' ability to secure electoral benefits from pork-barrel politics, gerrymandering, strategic entry and exit in elections or increased public visibility due to greater media coverage (Cox and Katz, 2002; Franklin, 1991). Especially if incumbents emphasize policy issues in their campaign, this increases voters' clarity of perception of incumbent parties and candidates (Franklin, 1991).

The reasoning underlying Hypothesis 2 implies, of course, that if a party is the incumbent at the subnational but not at the national level during the subnational campaign, this makes it not only substantially more difficult for citizens to learn about the true performance of this party, but also reminds voters of the complexity of political decisionmaking. Thereby, heterogeneity in party incumbency may eventually neutralize the informational effect of subnational elections, in that they lead citizens to think of the complexity of politics and this may outweigh the enlightening effect of subnational election campaigns.

A final factor moderating the informational value of subnational election campaigns is shifts in the governing coalition. Coalition governments are a central feature of many electoral systems and can be found at both the national and the subnational level. Governing parties that aim at a change in their coalitional partners regularly use the campaign to communicate their changing coalition preferences (Bräuninger and Debus, 2008). This severely limits citizens' ability to use information from subnational election campaigns to sharpen their national-level as it makes party images less precise. Instability in coalition preferences at the state level not only casts doubt on how informative past performance is for predicting a party's future public policy decisions. It also forces voters to compare and assess the potentially large variety of coalitional options, and thus, the likely policies that will result from their electoral choices. These challenges appear so severe, that subnational election campaigns that potentially involve coalitional shifts can offset the informational value of campaigns. In the context of potential coalitional shifts, subnational elections may therefore add to voter confusion, as the associated campaign emphasizes the uncertainty about which electoral option and public policy will eventually result, and voters may even start to question a party's national-level policy stance. Overall, subnational election campaigns which involve a potential coalition change should therefore increase citizens' uncertainty about their electoral preferences, resulting in higher vote intention volatility.

\footnotetext{
7 This data comes from Forsa, a renowned German polling institute, which offers the longest weekly time series going back to 1991. I examined the correlations of the Forsa time series with those of two other popularity series by different polling institutes (Emnid and Infratest) starting in 1998. The correlations for SPD and CDU vote intentions are very high (between .78 and .93 with $p<.000$ ). This indicates that there are no systematic deviations between these popularity measures. In addition, I examined cross-correlograms which clearly suggest that while all lead and lag correlations are significantly positive, the cross correlations between the time series peak at lag 0, i.e., the contemporaneous correlations are higher than any other correlation with lags or leads. Against this background and since the Forsa data offers much more data points, I opted for using this time series.
}

Hypothesis 3. (Coalitional shift) Subnational elections campaigns that involve a change in the governing coalition are associated with an increase in the volatility of nationallevel vote intentions.

\section{Empirical evaluation}

This section empirically evaluates hypotheses about bottom-up volatility spillovers in multi-level systems using weekly vote intention data from Germany (1992 to 2007). ${ }^{7}$ Germany has a federal system which consists of 16 states (Bundesländer). In each state, staggered elections to the state parliament are held. Unlike in the United States, where House elections occur every two years and presidential elections are held every four years, in Germany the timing of state elections is not synchronized with the federal election cycle, thereby nicely generating cases with which the informational effect of state election campaigns can be isolated from the impact of federal election campaigns. Also, all major parties competing for votes at the federal-level run for office in state elections, which results in the type of multi-level electoral competition (Debus, 2008) needed to test the hypotheses put forward in the theory.

\section{Federal-level vote intentions}

Fig. 1 plots the aggregate weekly federal-level vote intention series for the two major German parties, the Social Democratic Party (SPD) and the Christian Democratic Union (CDU). ${ }^{8}$ In both vote intention series, large (small) changes tend to follow large (small) changes, a phenomenon known as volatility clustering. Consider SPD popularity around the first week of 1995 (1995w1), for example. Vote intentions did not change much during this period (low volatility). But in the second half of 1995, popularity started to vary strongly (high volatility). Further scrutiny underscores the impression that the vote intention series exhibits volatility clustering. Using a naive notion of volatility, the black line in Fig. 1 plots the variability on the basis of a 20-weeks rolling standard deviation function. This function reveals the time-varying variance in vote intentions. There are periods of high and periods of low vote intention volatility. CDU volatility was relatively high, for example, in mid 1992 with about 3 percentage points on average, or in the first weeks of 2002 (more than 6 percentage points). While volatility in both SPD and CDU vote intentions share many similarities (the correlation between the two volatility series is -.427 with $p<.000$ ), Fig. 1 suggests that there still exist notable differences. For example, the average variability in CDU vote intentions exceeded four percentages points in 1994. In that same

\footnotetext{
8 The CDU time series includes CSU vote intentions. There are two reasons which prevent the use of data prior to 1992. The first is that German reunification has altered party competition in such a fundamental way (Kopstein and Ziblatt, 2006), that the probability of a structural break in the time series would be extremely high. Second, weekly vote intention data only exists since late 1991. Polling data which go further back in time (the so called Politbarometer data) is only of monthly frequency, which would be inappropriate to evaluate effects of relatively short subnational election campaign periods.
} 

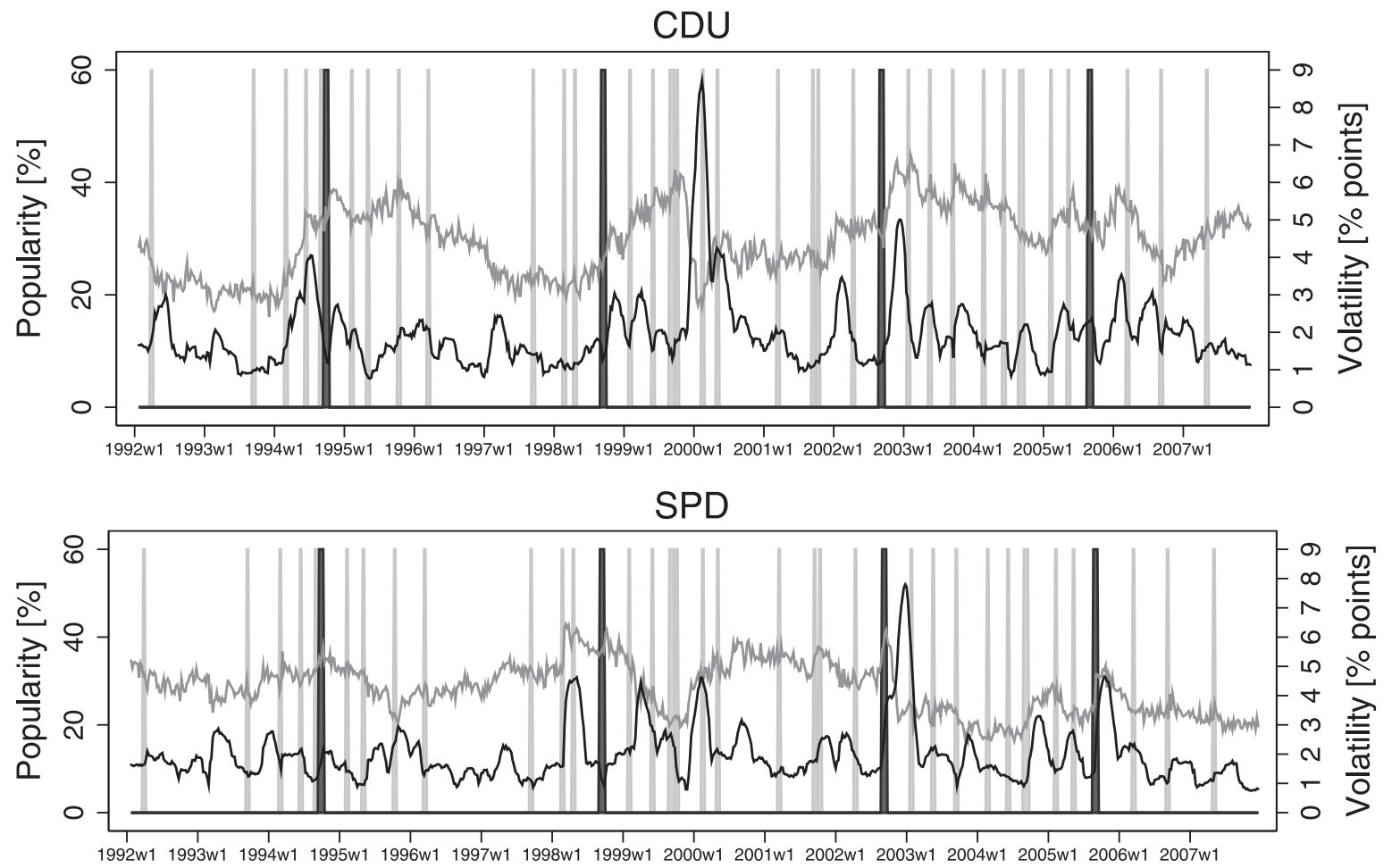

2002w1 1993w1 1994w1 1995w1 1996w1 1997w1 1998w1 1999w1 2000w1 2001w1 2002w1 2003w1 2004w1 2005w1 2006w1 2007w1

\begin{tabular}{|l|l|l|l|l}
\hline Popularity & Solatility elec. $\square$ Federal elec. \\
\hline
\end{tabular}

Fig. 1. Federal-level Vote Intentions, Unconditional Volatility, and State Election Campaigns (CDU and SPD, 1992-2007). Note: Weekly federal-level vote intention data (gray line). Unconditional volatility estimated using a 20 -weeks rolling standard deviation function (black line). The light gray-shaded area indicates a two weeks state election campaign window. The dark gray-shaded area indicates a four weeks federal election campaign window.

period, SPD vote intentions remained relatively stable and fluctuated only at around two percentage points on average.

Such visual inspection does not substitute for statistical testing. To explore whether the time series indeed exhibit volatility clustering, I examine the autocorrelation structure of the residuals from an auxiliary regression, in which I regressed the vote intention series on a constant. ${ }^{9}$ The results from Ljung-Box tests clearly suggest that there is a high degree of serial correlation in both the residuals as well as the squared residuals. Furthermore, the ARCH$\mathrm{LM}(1)$ test rejects the null of constant variance at the $1 \%$ significance level. As is well known, volatility clustering reduces the efficiency of OLS estimates and therefore, timevarying variance is often considered as something to be corrected for.

However, already Downs and Rocke (1979) point out "that the presence of heteroskedasticity and its subsequent exploration can yield various types of substantive knowledge" (819) and Beck (1983) proposes techniques which allow the researcher to explicitly model timevarying features of time series data. Therefore, in the empirical estimation this study appliesa Generalized Autoregressive Conditional Heteroskedasticity (GARCH) model to estimate the relationships between subnational election campaigns and volatility in national-level vote intentions.

\footnotetext{
${ }^{9}$ The results can be found in the web appendix.
}

\section{Estimating volatility spillover effects of subnational election campaigns}

I analyze vote intention series for all major (SPD and CDU) and the two minor parties (FDP and Greens) that compete in the German party system. To address that the dependent variable is bounded (between 0 and 1 ) and the vote intentions should sum up to one, I first define party $i$ 's popularity $s_{i, t}$ at time $t$ relative to the popularity of all parties I included in the analysis. Thus, $s_{i, t}:=r_{i, t} / \sum_{j \in I \backslash\{i\}} r_{j, t}$, where $r$ is the raw popularity. To remove the bounds I use a probit transformation. ${ }^{10}$ More precisely, party $i$ 's probit popularity $p_{i, t}$ is given by $p_{i, t}=\Phi\left(s_{i, t}\right)$, where $s_{i, t}$ denotes a party's popularity at time $t$ and $\Phi$ is the inverse cumulative distribution function for the normal distribution (probit function). ${ }^{11}$

To evaluate volatility effects of subnational election campaigns and to appropriately model the specific timeseries characteristics of the vote intention data, I employ a Generalized Autoregressive Conditional Heteroskedasticity

\footnotetext{
${ }^{10}$ PDS popularity cannot be included in the analysis, because this party has never been a member of the governing coalition at the federal level and only very rarely formed part of a state government. Since its nationwide, federal-level popularity is negligibly small, ignoring this party will not notably affect the relative popularity of other parties.

11 Since the conditional volatility model employed for the empirical estimation assumes that errors are drawn from a normal distribution, I deliberately opt for the probit instead of the logit function.
} 
(GARCH) modeling strategy (Engle, 1982; Bollerslev, 1986). Let the mean equation be defined as:

$p_{t}=\mu+\xi L_{t}+z_{t} \sqrt{h_{t}}$,

where $p_{t}$ is the party's probit popularity $p$ at time $t, \mu$ is a constant, $L_{t}$ is a vector of exogenous variables, and $z_{t}$ is a white noise process with finite variance. ${ }^{12}$ The corresponding conditional variance in case of a $\operatorname{GARCH}(1,1)$ model is

$h_{t}=\omega+\alpha \varepsilon_{t-1}^{2}+\beta h_{t-1}$,

where $\omega$ is a constant, $\varepsilon_{t-1}^{2}$ is the prior shock (ARCH term), and $h_{t-1}$ is the past variance (GARCH term).

The GARCH perspective on volatility fundamentally differs from how most previous work has conceptualized "volatility" in electoral outcomes or vote intentions. Previous research simply first-differenced the dependent variable and this notion of "volatility" often was equated with the degree of predictability or uncertainty in vote intentions or electoral outcomes. Viewed within a GARCH framework, this notion of volatility appears insufficient for a straightforward reason. Suppose vote intentions (or election results) change considerably from one period to another, but other factors, for example, economic conditions, explain these changes well. Thus, even though vote intentions may vary strongly, they can still be predicted well, and therefore, the observed variability in vote intentions does not contain much surprise. However, in other periods the model may perform poorly, since our conditional expectation, i.e., the prediction based on the explanatory factors, fails to predict vote intentions well. This truly leaves us with increased uncertainty. In statistical terms, residuals reflect this uncertainty. Applying a GARCH estimation strategy allows me to explicitly analyze this uncertainty in the variance equation. The variance equation aids to evaluate whether the variables in the mean equation are systematically better predictors of vote intentions as a function of subnational election campaigns and the conditions under which they take place.

To evaluate the theoretical predictions, I add six variables to the variance equation. ${ }^{13}$ The first is an indicator variable State Elec. Campaign that counts the number of weeks until the next state election in the two weeks preceding state elections and is 0 otherwise. ${ }^{14}$ Stevenson and Vavreck (2000) study inspired the choice of the campaign window length. They assign an election campaign length of six months in their study of campaign effects during national legislative elections in 13 countries and argue that this is an appropriate coding procedure as voters only pay attention to campaign information when an election is upcoming. Since subnational election campaigns are much shorter and tend to draw attention only immediately prior to the election, I opted for a very event window of two weeks. ${ }^{15}$

\footnotetext{
12 Note that $\mu$ does not need to be indexed by $t$, because it is a constant.

13 Table 1 provides details about the variables and data sources.

14 Table A1 of the web appendix (available at http://www.ib.ethz.ch/ people/mbechtel) provides a list of all state elections from 1992 to 2007.

15 In the appendix I report results for a three weeks campaign window.
}

If state election campaigns alone have affect citizens' electoral preferences, volatility in federal-level vote intentions should be lower in the weeks prior to a state election, i.e., the coefficient for State Elec. Campaign should be significant and of negative sign. This operationalization rests on the simplifying assumption that subnational elections receive equal national coverage, thereby "treating" all voters by providing them with information that affect their federal-level electoral preferences. Note, however, that this choice will provide an average estimate of the relationships between subnational election campaigns and national-level vote intentions, because the coefficient on the state election campaign variable will indicate the average effect of campaigns in states that receive less nation-wide media coverage and those in larger states that tend to receive more national coverage.

Two party-specific indicator variables account for state incumbency and federal incumbency effects. The variable State Incumbency equals 1 during the two weeks preceding state elections if a party enjoys incumbency in a state with upcoming elections. ${ }^{16}$ The second party-specific incumbency indicator is Federal Incumbency. This variable equals 1 if a party holds government at the national level. The interaction between these two variables, Congruence, indicates whether a party is incumbent at both the federal level and in a state in which an election is upcoming. The variable Coalitional Shift indicates whether a subnational election was associated with a change in the subnational coalition government. ${ }^{17}$ The variable Federal Elec. Campaign picks up influences from the most intense period of the federal election campaign. It equals 1 in the four weeks preceding federal elections and is 0 otherwise. Table 1 provides a summary of the variables, their operationalization, and data sources.

\section{Results}

Due to the probit transformation applied to the dependent variable, the coefficients are originally estimated in terms of $z$-values. To facilitate the interpretation and

\footnotetext{
16 The use of such a campaign-related incumbency indicator is very similar to Jackson (1997) approach who uses an interaction with a dummy variable to "turn on" and "turn off" campaign variables in his analysis of turnout in national, senatorial, and gubernatorial elections. The incumbency indicator variable is set to 1 if a party is a member of the state government in the two weeks prior to a state election and is 0 otherwise.

17 Originally, I intended to create an additional variable that reflects whether a shift in the governing coalition was surprising or not. A change would be surprising if a party refused to form a coalition with another party during the electoral campaign, but then after the election, this coalition eventually formed. However, as Bräuninger and Debus (2008, 327) show in their analysis of coalition formation in the German states (1990-2007), out of 546 negative coalition statements, zero coalitions eventually formed. This prevents the authors from including "surprising" changes in coalition governments as an explanatory factor in their statistical model Bräuninger and Debus (2008, 327, fn 11). Likewise, in this paper I cannot use this variable, because such a surprising shift in coalitional partners never happened. The Ypsilanti case, in which the SPD ignored its own negative coalition statement, occurred in March 2008 and is therefore neither included in my nor in Bräuninger and Debus (2008) sample.
} 
Table 1

Variables and data sources.

\begin{tabular}{|c|c|c|}
\hline Variable & Coding & Source \\
\hline Federal-level vote intentions & $\begin{array}{l}\text { Constructed from polling data based on surveys } \\
\text { conducted by Forsa. The corresponding question } \\
\text { is: "And which party would you vote for if federal } \\
\text { elections took place next Sunday?" (German version: } \\
\text { "Und welche Partei wuerden Sie waehlen, wenn am } \\
\text { naechsten Sonntag Bundestagswahl waere?" }\end{array}$ & $\begin{array}{l}\text { GESIS - Leibniz Institute for the Social Sciences } \\
\text { (dataset identification codes: ZA3380, ZA3300, } \\
\text { ZA2982, ZA3063, ZA2983, ZA2984, ZA2985, } \\
\text { ZA3162, ZA3289, ZA3486, ZA3675, ZA3909, } \\
\text { ZA4070, ZA4192, ZA4343, ZA4514, ZA4552). }\end{array}$ \\
\hline State election campaign & $\begin{array}{l}\text { Indicator variable that counts the number of weeks } \\
\text { until the upcoming state election in the two weeks } \\
\text { prior to a state election and is } 0 \text { otherwise. }\end{array}$ & http://www.election.de/ltw.html \\
\hline Federal election campaign & $\begin{array}{l}\text { Indicator variable that equals } 1 \text { in the four weeks } \\
\text { prior to a federal election and is } 0 \text { otherwise. }\end{array}$ & $\begin{array}{l}\text { www.bundeswahlleiter.de/en/bundestagswahlen/ } \\
\text { fruehere_bundestagswahlen/index.html }\end{array}$ \\
\hline State incumbency & $\begin{array}{l}\text { Indicator variable that equals } 1 \text { if party is the } \\
\text { incumbent in a state in the two weeks prior } \\
\text { to a state election and is } 0 \text { otherwise. }\end{array}$ & $\begin{array}{l}\text { GESIS - Leibniz Institute for the Social } \\
\text { Sciences, DVD “Landtagswahlen 1960-2004” } \\
\text { (V2.0), http://de.wikipedia.org/wiki/Ergebnisse_ } \\
\text { der_Landtagswahlen_in_der_Bundesrepublik_- } \\
\text { Deutschland, www.election.de/ltw.html }\end{array}$ \\
\hline Federal incumbency & $\begin{array}{l}\text { Indicator variable that equals } 1 \text { if a party is member } \\
\text { in the coalition government at the federal level and } \\
\text { is } 0 \text { otherwise. }\end{array}$ & $\begin{array}{l}\text { http://en.wikipedia.org/wiki/List_of_ } \\
\text { German_Governments }\end{array}$ \\
\hline Congruence & $\begin{array}{l}\text { Indicator variable that equals } 1 \text { if a party is member in } \\
\text { the coalition government at the federal level and in the } \\
\text { state in which an election is upcoming and is } 0 \text { otherwise. }\end{array}$ & $\begin{array}{l}\text { See sources for federal and state } \\
\text { incumbency variable }\end{array}$ \\
\hline Coalitional shift & $\begin{array}{l}\text { Indicator variable that equals } 1 \text { in case of a change in the } \\
\text { governing coalition and is } 0 \text { otherwise }\end{array}$ & $\begin{array}{l}\text { Detailed state election reports published in } \\
\text { the Zeitschrift für Parlamentsfragen; GESIS } \\
\text { - Leibniz Institute for the Social Sciences, } \\
\text { DVD “Landtagswahlen 1960-2004” (V2.0); } \\
\text { www.election.de/ltw.html }\end{array}$ \\
\hline Second chamber & $\begin{array}{l}\text { Indicator variable that equals } 1 \text { if the party controls } \\
\text { the majority of seats in the second chamber and is } \\
0 \text { otherwise } \\
\text { (only for SPD and CDU) }\end{array}$ & $\begin{array}{l}\text { Documents provided by the Bundesrat (available } \\
\text { from the author upon request) }\end{array}$ \\
\hline Inflation & & Thomson Financial Datastream \\
\hline Unemployment & & $\begin{array}{l}\text { Central Bank of the Federal Republic of Germany } \\
\text { (Deutsche Bundesbank), www.bundesbank. } \\
\text { de/statistik/statistik_zeitreihen.php\%3flang= } \\
\text { de\&open=\&func=row\&tr=UUCC02 }\end{array}$ \\
\hline
\end{tabular}

present the results in intuitively understandable quantities, I converted the coefficients into percentage points. Fig. 2 presents the results for both CDU and SPD vote intentions graphically. The upper two graphs show the estimates for the mean equation. The campaign period prior to state elections reduces nation-wide support for the SPD. Federal elections tend to increase support for the Social Democrats and decrease CDU popularity. The coefficient on Congruence suggests that CDU popularity at the federal level benefits from a joint switch from federal opposition status and the state in which an election is upcoming to federal incumbency and state incumbency. Both parties strongly benefit from controlling the majority of the second chamber, although to a different extent.

To account for a major event that should have affected electoral preferences at the end of 1999, the indicator variable CDU scandal helps to pick up the shift in vote intentions due to the discovery of the CDU having accepted illegal donations in the 1990s. The variable equals 1 from mid November 1999 to mid February 2000 and is 0 otherwise. Unsurprisingly, the scandal significantly decreased CDU popularity and boosted SPD support. The corresponding coefficients suggest that the CDU contributions scandal was costly to the CDU in terms of electoral support, as it was associated with a decrease in its popularity of about 2.5 percentage points, while at the same time increasing support for the Social Democrats of about 2 percentage points.

The two panels at the bottom of Fig. 2 display the coefficients from the variance equation graphically. Since the variance equation contains several multiplicative terms that are necessary to evaluate the theoretical predictions, there is not much use in interpreting the coefficients. Instead, I compute the marginal effects and corresponding confidence intervals from (Bollerslev and Wooldridge, 1992) semi-robust standard errors. I report the results below. As will become clear, the context in which subnational elections take place is crucial to our understanding of bottom-up volatility spillover effects.

Fig. 2 includes a table which reports results from several post-estimation diagnostic tests. ${ }^{18}$ Autocorrelation tests

\footnotetext{
18 The table reports information criteria like the AIC, because in the case of GARCH models the $R^{2}$ is not an appropriate goodness of fit measure.
} 




Graphs by party

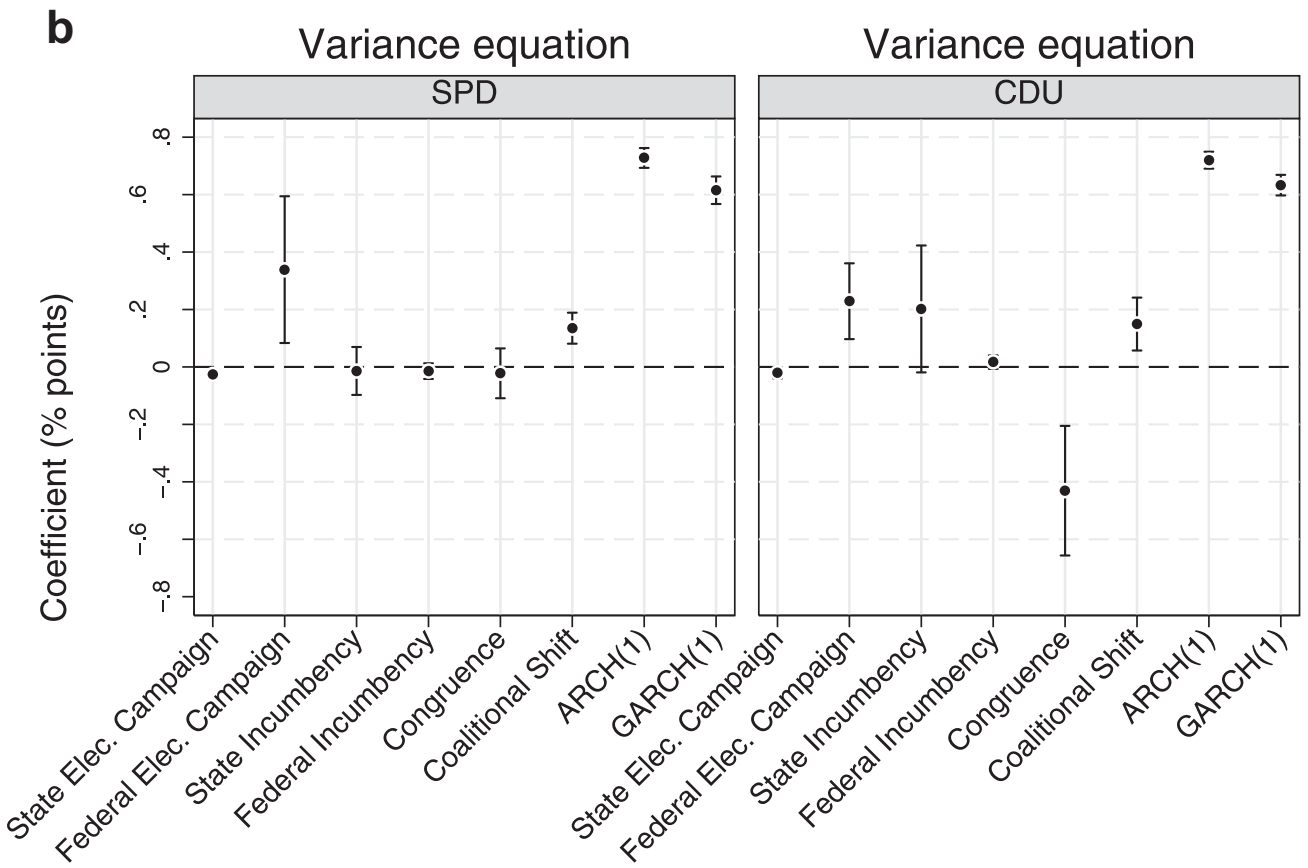

Graphs by party

\begin{tabular}{lll} 
& SPD & CDU \\
\hline AIC & -1.6 & -1.5 \\
$Q(5)$ & $1542.5^{* * *}$ & $1716.6^{* * *}$ \\
$Q(5)^{2}$ & 3.7 & 4.8 \\
ARCH-LM $(1)$ & .2 & .3 \\
JB & $15.9^{* * *}$ & $27.6^{* * *}$ \\
N & 834 & 834 \\
\hline
\end{tabular}

Fig. 2. The Correlates of Federal-level Vote Intentions: CDU and SPD, 1991-2007. Note: The upper two panels (a) present GARCH(1,1) mean equation results. The lower two panels (b) report variance equation results (left panels: SPD, right panels: CDU). Dots represent point estimates, vertical lines depict $90 \%$ confidence intervals computed from Bollerslev and Wooldridge (1992) semi-robust standard errors. Constant in mean and variance equation included, but not reported. Post-estimation diagnostic tests reported in table. Post-estimation diagnostic tests reported in table. AIC $=$ Akaike Information Criterion, $Q(5)$ and $Q(5)^{2}=\mathrm{Ljung}-\mathrm{Box}-\mathrm{Portmanteau}$ test statistic for residuals and squared residuals, ARCH-LM(1) $=\mathrm{ARCH}$ Lagrange multiplier, JB = Jarque-Bera, $N=$ number of observations. ${ }^{*} p<.10$, ${ }^{* *} p<.05$, ${ }^{* * *} p<.01$. 
suggest that there is some information left in the residuals, but not in the squared residuals, as the Ljung-Box test statistic for the squared residuals does not even reach a ten percent significance level. Therefore, the GARCH specification successfully accounted for the volatility clustering in the vote intention series. The ARCH-LM test underscores this impression, since it fails to reject the null hypothesis of no clustering in the residuals for both, SPD and CDU vote intentions. ${ }^{19}$ Fig. 3 shows the results for the two minor German parties, FDP and Greens. For the mean equation the estimates indicate that vote intentions are lower during periods in which these parties are part of the government at the federal level. Also, economic factors play a significant and substantial role for explaining variance in the mean of federal-level vote intentions.

For all parties, the ARCH and the GARCH terms are well contained in the unit interval and their sum is smaller than 1 , thereby satisfying several parameter restrictions the GARCH model is subject to. ${ }^{20}$ The ARCH and GARCH terms themselves contain interesting information about the vote intention volatility dynamics. For both CDU and SPD popularity the ARCH coefficient is clearly larger than the GARCH term. This suggests that although innovations induce a relatively strong volatility increase, these shocks are not very persistent.

To gain a numerical impression of the volatility dynamics, I calculated the half life $\lambda$ of a volatility shock. $\lambda$ measures the average time it takes for the conditional variance to decrease by one half and is given by $\lambda=\ln (1 / 2) / \ln (\alpha+\beta)$. The half life for SPD vote intentions is about 14 weeks and the half life for CDU vote intentions is nine weeks. This means that it takes approximately three and a half (two) months on average for SPD (CDU) conditional volatility to decrease by $50 \%$ after a shock has occurred. For the volatility in Greens and FDP vote intentions the half life is considerable shorter. $\lambda$ is about seven weeks for the Green party and about one week for FDP volatility. Thus, volatility shocks have a considerably less persistent impact on the variance in vote intentions for these two smaller parties.

\section{Campaign context, state election campaigns and federal-level vote intentions}

My key interest is in the marginal effects of the subnational election campaign variable and its interactions with other variables included in the variance equation. For example, Hypothesis 2 states that subnational campaign periods in which a party is the incumbent at the subnational and the national-level reduces volatility in support for that

\footnotetext{
$\overline{19}$ Bollerslev and Wooldridge (1992) show that maximum likelihood estimates of the parameters in a GARCH model are consistent even if the true distribution of the innovations is not Gaussian. Yet, the standard errors are inconsistent if the assumption of Gaussian errors is violated. Since Bollerslev and Wooldridge (1992) semi-robust standard errors are applied throughout the estimations, the inferences made are robust to deviations in the normality of the residuals.

20 Another parameter restriction is that the constant in the variance equation must be greater than zero. The figures do not display the constant to conserve space, but in all models this condition is satisfied.
}

party. An evaluation of this hypothesis requires computing the marginal effect of subnational election campaigns if the state incumbency variable is 1 and the federal incumbency variable equals 1. Also, Hypothesis 3 implies interactions between the subnational election campaign variable and other contextual variables. Therefore, an evaluation of these hypotheses necessitates calculating marginal effects as a linear combination of the relevant coefficients along with corresponding standard errors. These can be computed from the variance-covariance matrix of the coefficient estimates (Brambor et al., 2006; Kam and Franzese, 2007). Fig. 4 presents these marginal volatility spillover effects on federal-level vote intentions for all four parties. I first turn to the results for the two major parties, SPD and CDU.

According to the theoretical argument set out above, state election campaigns induce all voters in the country - not only those who are eligible to cast a vote in the upcoming state election - to form more precise estimates of the political and economic fundamentals that enter their electoral preferences. Thus, periods of state election campaigns should reduce conditional volatility in nation-wide vote intentions (Hypothesis 1). The marginal effect of subnational election campaigns is negative and significantly so for both federallevel volatility in SPD and CDU vote intentions. On average, volatility in national-level vote intentions decreases by about .02 percentage points during subnational election campaigns. This supports the argument about the informational role of subnational election campaigns.

If state elections take place under conditions of incumbency incongruence, i.e., a party holds government only at the state, but not at the national level, volatility in nationallevel vote intentions for CDU and SPD remain unaffected by the campaign. For both, SPD and CDU, the point estimates do not significantly differ from zero. This is consistent with the view that heterogeneity in incumbency at the subnational and the national-level neutralizes the informational value of subnational election campaigns. However, the volatility-reducing effect of subnational election campaigns is amplified for both the Social Democrats and the Christian Democrats, if these fall into a period in which they enjoy federal incumbency and incumbency in the state that has an upcoming election (Hypothesis 2). Federal-level popularity of the SPD among all citizens falls by about .1 percentage points on average during state election campaign periods if this party is the incumbent at both the federal level and in the state that has an upcoming election. This effect is significantly stronger for volatility in nationallevel CDU vote intentions (.22 percentage points).

The results for the two major German parties support the coalitional shift argument (Hypothesis 3). A change in the governing coalition moderates the relationship between subnational election campaigns and national-level vote intentions. If subnational elections are associated with a change in the state's governing coalition, volatility in support for the SPD and the CDU increases during the campaign period by about .1 percentage points on average. This suggests that changes in the state government's party draws voters' attention to political issues and party preferences nation-wide, but also make it more difficult for them to make up their minds, thereby increasing voter uncertainty as reflected by volatility in national-level vote 


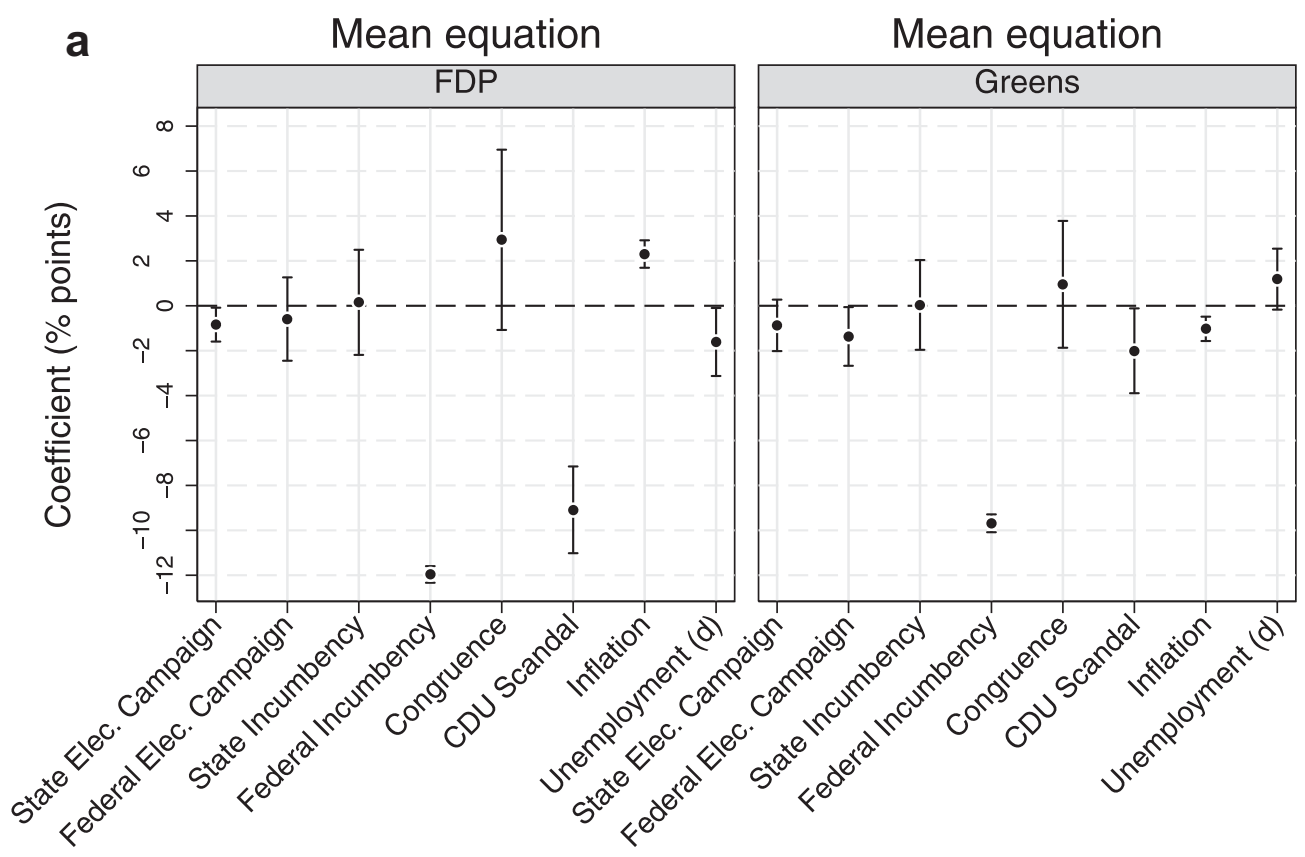

Graphs by party

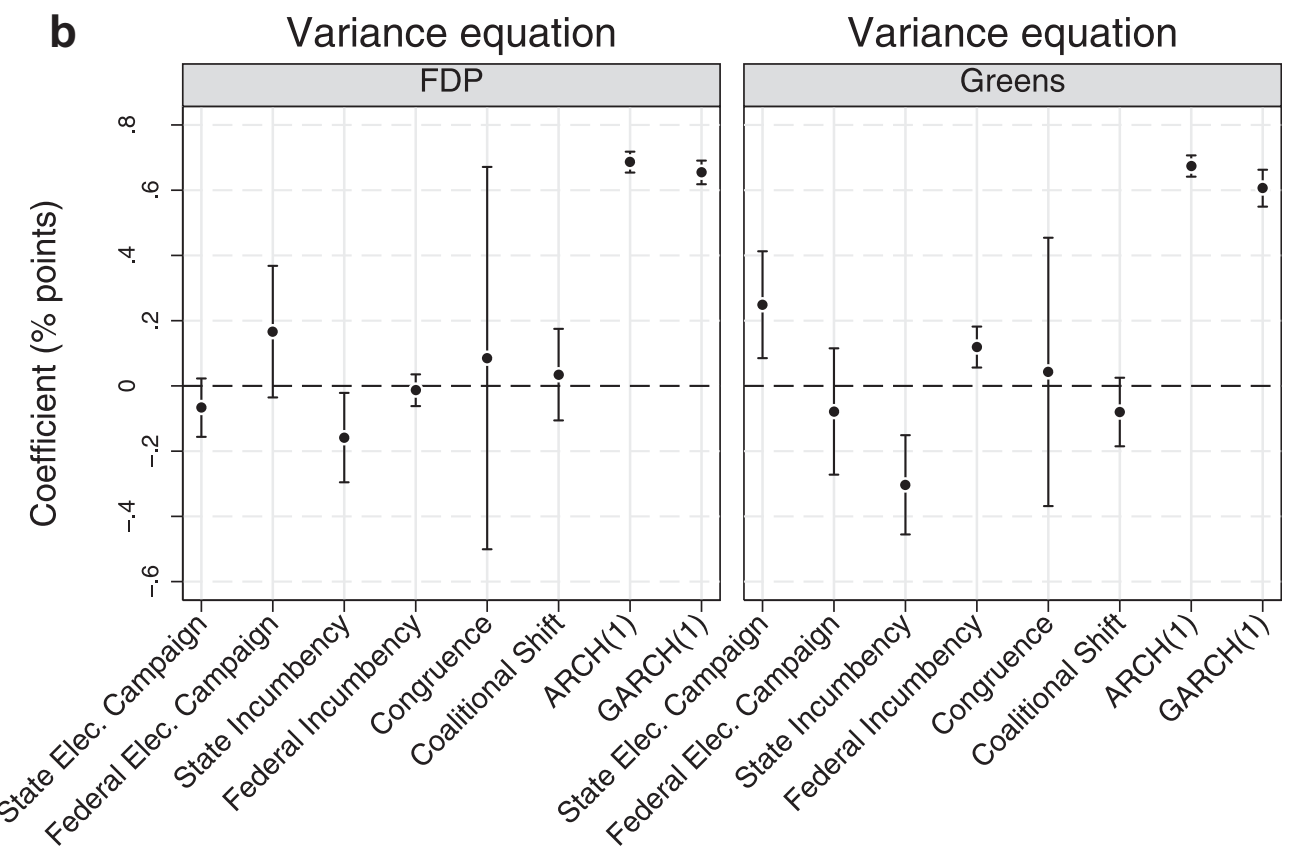

Graphs by party

\begin{tabular}{lll} 
& FDP & Greens \\
\hline AIC & -1.3 & -1.0 \\
$Q(5)$ & $1774.4^{* * *}$ & $1420.1^{* * *}$ \\
$Q(5)^{2}$ & $11.9^{* *}$ & 6.8 \\
ARCH-LM(1) & .0 & 1.0 \\
JB & 22.2 & $11.0^{* * *}$ \\
$\mathrm{~N}$ & 834 & 834 \\
\hline
\end{tabular}

Fig. 3. The Correlates of Federal-level Vote Intentions: FDP and Greens, 1991-2007. Note: The upper two panels (a) present GARCH(1,1) mean equation results. The lower two panels (b) report variance equation results (left panels: FDP, right panels: Greens). Dots represent point estimates, vertical lines depict 90\% confidence intervals computed from Bollerslev and Wooldridge (1992) semi-robust standard errors. Constant in mean and variance equation included, but not reported. Postestimation diagnostic tests reported in table. AIC = Akaike Information Criterion, $Q(5)$ and $Q(5)^{2}=$ Ljung-Box-Portmanteau test statistic for residuals and squared residuals, ARCH-LM(1) $=$ ARCH Lagrange multiplier, JB = Jarque-Bera. ${ }^{*} p<.10,{ }^{* *} p<.05,{ }^{* * *} p<.01$. 


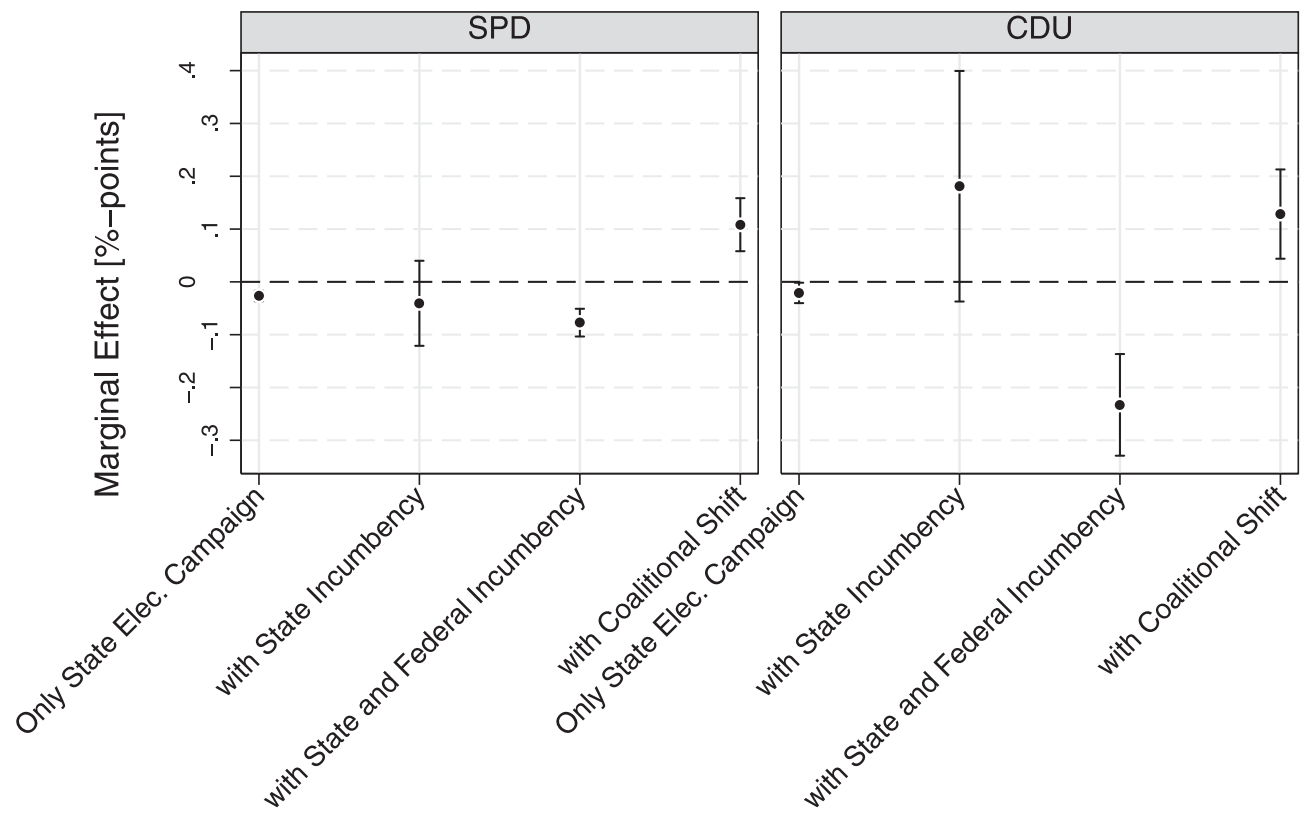

Graphs by party
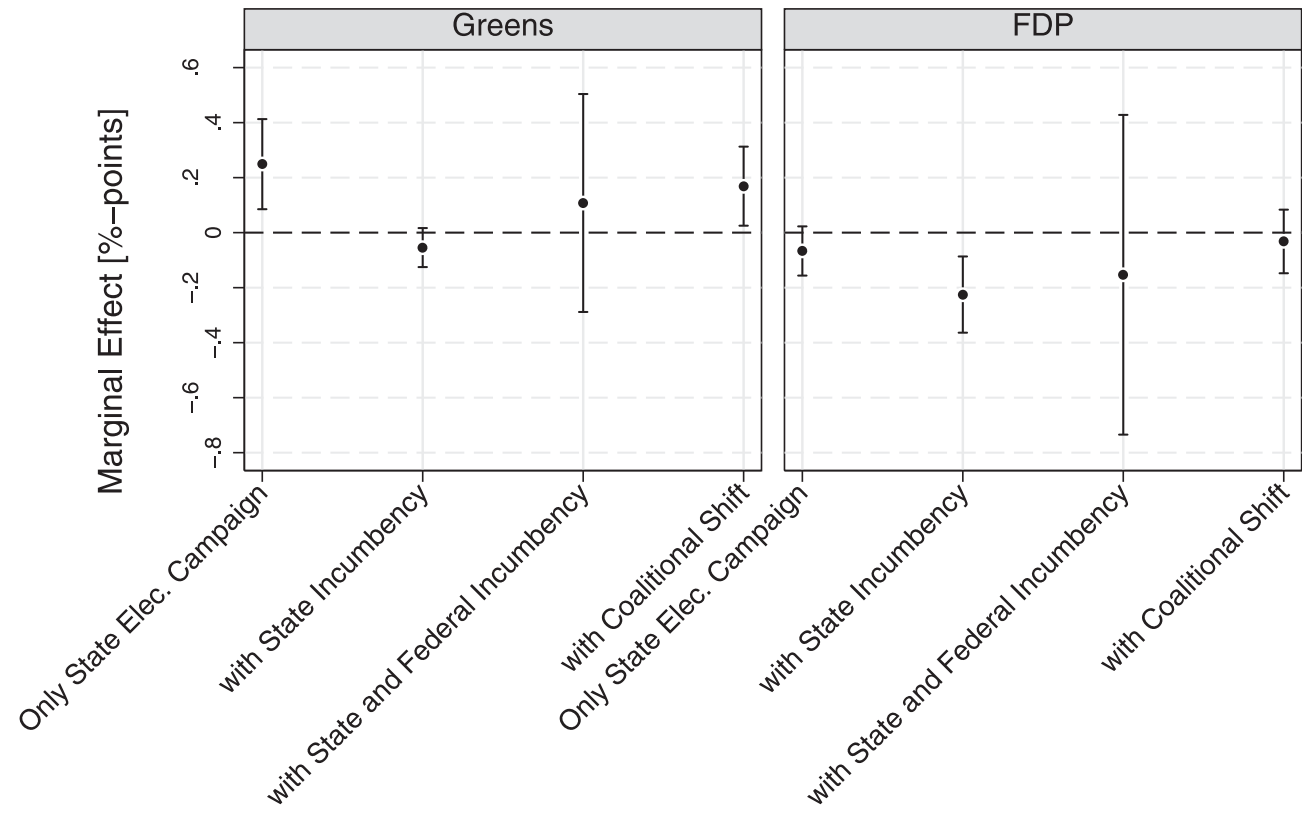

Graphs by party

Fig. 4. Context-Conditionality and Marginal Volatility Spillover Effects of State Election Campaigns on Federal-level Vote Intentions. Note: Dots represent marginal effects computed from GARCH(1,1) point estimates. Vertical lines depict 90\% confidence intervals based on Bollerslev-Woooldridge semi-robust standard errors.

intentions. This finding again holds for both major parties, SPD and CDU and is consistent with the view that changing coalition preferences make it more difficult for voters to compare and assess the coalitional options, and thus, the likely policies that will result from their electoral choices.

The lower panels in Fig. 4 shows the marginal effects for the Greens and the FDP, which are minor parties. These findings differ from those for the major parties. For the Green party subnational elections are associated with an increase in federal-level vote intention volatility as are subnational elections that involve a coalitional shift. For the
FDP, state election campaigns significantly reduce volatility in federal-level vote intentions only if that party also is part of the governing coalition in the state that has an upcoming election. If it also forms part of the governing coalition at the federal level (incumbency congruence), the point estimate is associated with a large confidence interval. In sum, this adds to the impression that there are notable differences in the effects between major and minor parties. In the conclusion I elaborate on potential explanations for these differences.

In the specifications reported above, a two weeks election counter variable proxied for state election campaign 
periods. I reestimated all models using a three weeks indicator variable. As one would expect, this somewhat reduces the precision with which the effects are estimated, although the main effects remain unchanged. In addition and in line with the theory, subnational election campaigns now significantly reduce volatility in FDP popularity.

\section{Conclusion}

This paper explores the role of subnational elections for uncertainty in citizens' electoral preferences at the national level (bottom-up volatility spillovers) and thereby adds to scholarship on interaction effects among electoral institutions. Campaigns raise interest in political and economic issues and inform citizens about variables that enter their vote choice (e.g., party characteristics and economic performance). In political systems where strong parties operate at both the national and the subnational level, subnational elections provide an opportunity for all citizens (not just those in the subnational jurisdiction facing an election) to learn about variables that determine their party preferences. This reduces voters' uncertainty about their electoral preferences.

Since subnational elections induce the media to cover political and campaign-related issues in nation-wide television channels, radio stations, and newspapers in the run-up to election day, all citizens can sharpen their electoral preferences. At the aggregate level, this should lead to a bottomup volatility spillover, i.e., a reduction in the conditional variability of national-level vote intentions during subnational election campaigns among citizens throughout the country. The role of subnational elections also depends on the clarity of responsibility in multi-level systems. Multi-level systems can complicate an assessment of parties' incumbency performance, because partisanship of subnational governments and partisanship of the national government may differ. Also, instability in a party's coalition preferences moderates the informational value of subnational election campaigns, because it makes party images less precise and complicates a comparison of the coalitional options, and thus, the likely policies that result from citizens' electoral choices.

The results partly support, but at the time challenge the theory and provoke interesting questions for further research. For the major parties, subnational election campaigns reduce volatility in vote intentions, which is in line with the theory. Moreover, if a major party forms part of the governing coalition in the state that faces an election, the subnational campaign leads to a decrease in the volatility of federal-level vote intentions. While past research has documented a considerable incumbency advantage, this finding suggests that incumbency in addition provides major parties with an opportunity to stabilize electoral support. Instability in state-level coalition preferences of the two major German parties, SPD and CDU, lead to positive volatility spillover effects of state election campaigns on federal-level vote intentions.

Overall, the findings underscore that an understanding of the informational role of subnational elections requires looking at the conditions under which they take place. More generally, the evidence indicates that multi-level electoral systems in which subnational and national electoral cycles are unsynchronized can entail additional electoral costs and benefits in the form of bottom-up volatility spillovers. Thus, to the extent domestic party support constitutes a bargaining resource in international politics, subnational elections and the conditions which surround them may also play a role for how willing governments are to engage in international negotiations.

A limitation of this study is its exclusive use of macrolevel data. Subsequent research may therefore explicitly derive empirical implications of the theory at the microlevel, in particular, on the context-conditional campaign effects of subnational election campaigns on voter preferences, and analyze individual-level data to more fully examine the validity of the theory.

Two final remarks can be made that concern the generalizability of the results and the differences in findings for major and minor parties. First, I have analyzed data from Germany and one may wonder about whether the results have the potential to generalize to other countries. Since other countries have multi-level electoral systems and a nationalized party system (for example, Brazil, Sweden, and Japan), the primary conditions for the theory to be applicable are met. At the same time, I acknowledge the possibility that in these systems additional factors may play a role, for example, the electoral system used at different levels or district magnitude. Overall, however, the findings presented in this paper seem to encourage an analysis of bottom-up volatility spillovers in these multi-level systems.

Second, a simple yet interesting question arises from the finding that the volatility effects of subnational election campaigns seem to be mainly restricted to the major parties. What can explain this difference? I can think of at least two possible explanations that relate to parties' communication qualities and media effects as well as policy heterogeneity and recruitment issues.

Major and minor parties may simply differ in their ability (or willingness) to reveal general party characteristics in their electoral campaign. In particular, major parties potentially enjoy a systematic advantage with respect to media coverage prior to elections, which affects their success in communicating information about the political and economic fundamentals. In fact, these differences would become especially effective during subnational election campaigns, thereby producing the type of bottom-up volatility spillovers of subnational elections on electoral support for major parties.

A complementary explanation draws on the existence of systematic differences in policies and candidate characteristics between minor and major parties. Minor parties could pursue policies and recruit candidates at the nationallevel which strongly differ from those at the subnational level. Citizens should take this into account and recognize that there is little to learn from subnational elections about minor parties at the national level. Future research could explore these and other possible explanations for the observed differences in bottom-up volatility spillovers on vote intentions across major and minor parties.

\section{References}

Alesina, A., Rosenthal, H., 1995. Partisan Politics, Divided Government, and the Economy. Cambridge University Press, Cambridge/New York. Anderson, C.J., Ward, D.S., 1996. Barometer elections in comparative perspective. Electoral Studies 15 (4), 447-460. 
Bechtel, M.M., Hainmueller, J., 2011. How lasting is voter gratitude? An analysis of the short- and long-termelectoral returns to beneficial policy. American Journal of Political Science 55 (4), 852-868.

Beck, N., 1983. Time-varying parameter regression models. American Journal of Political Science 27 (3), 557-600.

Bollerslev, T., 1986. Generalized Autoregressive conditional heteroscedasticity. Journal of Econometrics 31 (3), 307-327.

Bollerslev, T., Wooldridge, J.M., 1992. Quasi-maximum likelihood estimation and inference in dynamic models with time-varying covariances. Econometric Review 11 (2), 143-172.

Bräuninger, T., Debus, M., 2008. Der Einfluss von Koalitionsaussagen, programmatischen Standpunkten und der Bundespolitik auf die Regierungsbildung in den deutschen Ländern. Politische Vierteljahresschrift 49 (2), 309-338.

Brambor, T., Clark, W.R., Golder, M., 2006. Understanding interaction models: improving empirical analyses. Political Analysis 14 (1), 63-82.

Clarke, H.D., Stewart, M.C., Whiteley, P.F., 1998. New models for New Labour: the political economy of Labour party support, January 1992April 1997. American Political Science Review 92 (3), 559-575.

Cox, G.W., Katz, J.N., 2002. Elbridge Gerry's Salamander. Cambridge University Press, Cambridge.

Cox, K.E., Schoppa, L.J., 2002. Interaction effects in mixed-member electoral systems. Comparative Political Studies 35 (9), 1027-1053.

Debus, M., 2008. Party competition and government formation in multilevel settings: evidence from Germany. Government and Opposition 43 (4), 505-538.

Decker, F., von Blumenthal, J., 2002. Die bundespolitische Durchdringung der Landtagswahlen. Eine empirische Analyse von 1970 bis 2001. Zeitschrift für Parlamentsfragen 33 (1), 144-165.

Dinkel, R., 1977. Der Zusammenhang zwischen Bundes- und Landtagswahlergebnissen. Politische Vierteljahresschrift 18 (2), 348-359.

Downs, G.W., Rocke, D.M., 1979. Interpreting heteroscedasticity. American Journal of Political Science 23 (4), 816-828.

Duverger, M., 1986. Electoral Laws and Their Political Consequences. Agathon, New York.

Engle, R.F., 1982. Autoregressive conditional heteroscedasticity with estimates of the variance of U.K. Inflation. Econometrica 50 (4), 987-1008.

Fiorina, M.P., 1991. Divided government in the states. PS: Political Science and Politics 24 (4), 646-650.

Fiorina, M.P., 1978. Economic retrospective voting in American national elections: a micro-analysis. American Journal of Political Science 22 (2), 426-443.

Finkel, S.E., 1993. Reexamining the 'Minimal effects' model in recent presidential campaigns. Journal of Politics 55 (1), 1-21.

Franklin, C.H., 1991. Eschewing Obfuscation? Campaigns and the perception of U.S. senate incumbents. American Political Science Review 85 (4), 1193-1214.

Gaines, B.J., Crombez, C., 2004. Another look at connections across German elections. Journal of Theoretical Politics 16 (3), 289-319.

Gelman, A., King, G., 1993. Why are American Presidential Presidential election campaign polls so variable when votes are so predictable. British Journal of Political Science 23 (4), 409-451.

Gerber, E.R., Lupia, A., 1995. Campaign competition and policy responsiveness in direct legislation election. Political Behavior 17 (3), 287-306.

Gronke, P., Brehm, J., 2002. History, heterogeneity, and presidential approval: a modified ARCH approach. Electoral Studies 21 (3), 435-452.

Gschwend, T., 2007. Berliner Abgeordnetenwahlen 1979 bis 2001: keine Testwahlen für die Bundesebene. Zeitschrift für Parlamentsfragen 38 (3), 531-540.

Geschwend, T., Leuffen, D., 2005. Divided we stand - unified we govern? Cohabitation and regime voting in the 2002 French elections. British Journal of Political Science 35 (4), 691-712.

Hainmüller, J., Kern, H.L., 2008. Incumbency as a source of spillover effects in mixed electoral systems: evidence from a regression-discontinuity design. Electoral Studies 27 (2), 213-227.

Hennl, A., Kaiser, A., 2008. Ticket-balancing in mixed-member proportional systems. comparing sub-national elections in Germany. Electoral Studies 27 (2), 321-336.

Herron, E.S., Nishikawa, M., 2001. Contamination effects and the number of parties in mixed-superposition electoral systems. Electral Studies 20 (1), 63-86.
Jensen, J.M., Beyle, T., 2003. Of footnotes, missing data, and lessons for 50-state data collection: the gubernatorial campaign finance project, 1977-2001. State Politics and Policy Quarterly 3 (2), 203-214.

Jackson, R.A., 1997. The mobilization of U.S. State electorates in the 1988 and 1990 elections. Journal of Politics 59 (2), 520-537.

Jacobson, G.C., Kernell, S., 1983. Strategy and Choice in Congressional Elections. Yale University Press, New Haven/London.

Kam, C.D., Franzese, R.J., 2007. Modeling and Interpreting Interactive Hypotheses in Regression Analyses. University of Michigan Press, Michigan.

Karp, J.A., 2009. Candidate effects and spill-over in mixed systems: evidence from New Zealand. Electoral Studies 28 (1), 41-50.

Kedar, O., 2006. How voters work around institutions: policy balancing in staggered elections. Electoral Studies 25 (3), 509-527.

Kern, H.L., Hainmüller, J., 2006. Electoral balancing, divided government, and midterm loss in German state elections. Journal of Legislative Studies 12 (2), 127-149.

Kriner, D., Schwartz, L., 2009. Partisan dynamics and the volatility of presidential approval. British Journal of Political Science 39 (3), 609-631.

Kopstein, J., Ziblatt, D., 2006. Honecker's revenge. The enduring legacy of German unification in the 2005 election. German Politics and Society 24 (1), 134-147.

Lewis-Beck, M.S., Paldam, M., 2000. Economic voting: an introduction. Electoral Studies 19 (2), 113-121.

Lohmann, S., Brady, D.W., Rivers, D., 1997. Party identification, retrospective voting, and moderating elections in a federal system. Comparative Political Studies 30 (4), 420-449.

Matthews, J.S., Johnston, R., 2010. The campaign dynamics of economic voting. Electoral Studies 29 (1), 13-24.

Miller, W.L., Mackie, M., 1973. The electoral cycle and the asymmetry of government and opposition popularity: an alternative model of the relationship between economic conditions and political popularity. Political Studies 21 (3), 263-279.

Norris, P., Sanders, D., 2003. Message or medium? Campaign learning during the 2001 British general election. Political Communication 20 (3), 233-262.

Peterson, D.A.M., 2009. Campaign learning and vote determinants. American Journal of Political Science 53 (2), 445-460.

Powell, B.G., Whitten, G.D., 1993. A cross-national analysis of economic voting: taking account of the political context. American Journal of Political Science 37 (2), 391-414.

Putnam, R.D., 1988. Diplomacy and domestic politics: the logic of twolevel games. International Organization 42 (3), 427-460.

Reif, K., Schmitt, H., 1980. Nine second-order national elections: a conceptual framework for the analysis of European election results. European Journal of Political Research 8 (1), 3-44.

Samuels, D.J., 2000. The gubernatorial coattails effect: federalism and congressional elections in Brazil. Journal of Politics 62 (1), 240-253.

Schelling, T.C., 1960. The Strategy of Conflict. Harvard University Press, Cambridge (Mass.).

Schain, M.A., 2006. Immigration and changes in the French party system. European Journal of Political Science 16 (6), 597-621.

Scheve, K., Tomz, M., 1999. Electoral surprise and the midterm loss in US congressional elections. British Journal of Political Science 29(3),507-521.

Schultz, K.A., 1998. Domestic opposition and signaling in international crises. American Political Science Review 92 (4), 829-844.

Shaw, D.R., Roberts, B.E., 2000. Campaign events, the media and the prospects of victory: the 1992 and 1996 US presidential elections. British Journal of Political Science 30 (2), 259-289.

Selb, P., 2008. Supersized votes: ballot length, uncertainty, and choice in direct legislation elections. Public Choice 135 (3-4), 319-336.

Stevenson, R.T., Vavreck, L., 2000. Does campaign length matter? Testing for cross-national effects. British Journal of Political Science 30 (2), 217-235.

Wattenberg, M.P., 2000. The decline of party mobilization. In: Dalton, R.J., Wattenberg, M.P. (Eds.), Parties Without Partisans. Political Change in Advanced Industrial Democracies. Oxford University Press, Oxford, pp. 64-78.

Weisberg, H.F., 2002. Partisanship and incumbency in presidential elections. Political Behavior 24 (4), 339-360.

Wlezien, C., Erickson, R.S., 2002. The timeline of presidential election campaigns. Journal of Politics 64 (4), 969-993. 